AperTO - Archivio Istituzionale Open Access dell'Università di Torino

\title{
Being "hangry": food depletion and its cascading effects on social behaviour
}

\section{This is the author's manuscript}

Original Citation:

Availability:

This version is available http://hdl.handle.net/2318/1686824

since 2019-01-15T00:17:28Z

Published version:

DOI:10.1093/biolinnean/bly119

Terms of use:

Open Access

Anyone can freely access the full text of works made available as "Open Access". Works made available under a Creative Commons license can be used according to the terms and conditions of said license. Use of all other works requires consent of the right holder (author or publisher) if not exempted from copyright protection by the applicable law. 


\title{
Being "hangry": food depletion and its cascading effects on social behaviour
}

\author{
NICCOLÒ FATTORINI ${ }^{1}$, CLAUDIA BRUNETTI ${ }^{1}$, CAROLINA BARUZZI ${ }^{1}$, ELISABETTA MACCHI ${ }^{2}$, MARIA CHIARA \\ PAGLIARELLA $^{3}$, NOEMI PALLARI ${ }^{1}$, SANDRO LOVARI ${ }^{1,4 *}$ and FRANCESCO FERRETTI ${ }^{1}$ \\ ${ }^{1}$ Department of Life Sciences, University of Siena, Via P.A. Mattioli 4, 53100 Siena, Italy ${ }^{2}$ Department of Veterinary \\ Sciences, University of Torino, Via L. Da Vinci 44, 10095 Grugliasco (TO), Italy \\ ${ }^{3}$ Department of Bioscience and Territory, University of Molise, Via F. De Sanctis, 86100 Campobasso, Italy \\ ${ }^{4}$ Maremma Natural History Museum, Strada Corsini 5, 58100 Grosseto, Italy
}

*Corresponding author.E-mail: sandro.lovari@gmail.com

Abstract

Evolutionary theory suggests two alternative ways in which competitive interactions could vary in response to different levels of food abundance. Competition theory suggests that aggression should be greater when resource availability is lower, as an evolutionary stable strategy to access food. Alternatively, energy allocated to aggressive interactions should increase when the available spectrum of food resources is wider, in turn allowing a greater selec- tion. We tested these hypotheses on a group-living herbivore, the Apennine chamois, Rupicapra pyrenaica ornata. We compared social, aggressive and vigilance behaviour and relevant endocrine correlates across three areas: two 'poorer' areas, i.e. with a lower availability of nutritious pasture, and a 'richer' one. In the richer area, we observed: (1) the largest group size/greatest proportion of young individuals in groups; (2) the lowest rate/intensity of aggression between individuals, at feeding; (3) the lowest duration of vigilance and proportion of 'costly' vigilance, i.e. postures performed without chewing food; and (4) the lowest levels of testosterone and cortisol metabolites, suggesting a lower endogenous aggressiveness/stress response. Our findings agree with the competition theory, suggesting a role of food depletion in increasing aggression between foraging individuals, as an evolutionary stable strategy, with cascading effects on group phenology, vigilance and stress.

ADDITIONAL KEYWORDS: aggression - Apennine chamois - feeding interference - group size - herbivores intraspecific competition - Rupicapra pyrenaica ornata - social behaviour - stress - testosterone -vigilance.

\section{INTRODUCTION}

The availability of key resources is crucial for the sur- vival of wild species (Gause, 1932; Begon et al., 2006). Food resources have influenced the evolution of physi- omorphological traits, e.g. digestive/feeding adapta- tions (Bowman, 1961; Lee, 1980; Tauber \& Tauber, 1987; Hofmann, 1989; Meyer, 1989), and behaviour, e.g. social organization, mating system and spatiotem- poral behaviour (Jarman, 1974; Emlen \& Oring, 1977; De Groot, 1980; Macdonald, 1983). In turn, variation in food availability is likely to influence key aspects of behavioural ecology of wild animals, with consequences at individual and population levels (e.g. Pettorelli et al., 2002; Melis et al., 2009; but see Forsyth, 2000). For example, populations with different levels of food abundance may show different rates of competition and stress but, to our knowledge, relevant information is not available for free-ranging animals.

Within a social group, individuals can compete for the access to crucial resources. A scramble com- petition occurs when food is consumed and depleted before being used by other individuals (e.g. Kiley- Worthington, 1978; Gillman \& Crawley, 1990; Wise \& Wagner, 1992). A contest competition (or feeding inter-ference) occurs through direct interactions between individuals (e.g. Walde \& Davies, 1984; Symington, aggressive interactions between individuals can be considered as clues revealing intraspecific competi- tion (Miller, 1967). Evolutionary theory suggests two alternative ways through which competitive interac- tions could vary in response to different levels of food abundance. Classical competition theory suggests that intraspecific competition should be greater when availability of resources is lower (e.g. Volterra, 1926; Schoener, 1973; Titman, 1976). Accordingly, experimen- tal variations of food supply have provided evidence for intraspecific competition by resource exploitation when resources are scarce (Taitt \& Krebs, 1981; Krebs et al., 1986; Boyce, 1989). Yet, a 
greater level of aggres- sive interactions between individuals can be expected (Sirot, 2000). Alternatively, the energy allocated in competitive interactions could increase along with the value of a disputed resource (Parker, 1974; Enquist et al., 1985; Shopland, 1987). For example, according to Geist (1978), a great availability of resources can be expected to lead individuals to invest especially in body growth (e.g. weaponry), reproductive activities and social behaviours, whereas if resources are scarce, individuals should limit costly activities, e.g. social interactions. If so, agonistic interactions between indi- viduals would increase if resources were unlimited (Caraco, 1979; Goss-Custard et al., 1984). Determining which hypothesis is supported by data would help us to understand how the variation in the abundance of food resources, e.g. triggered by environmental modifi- cations or climatic changes, might affect key aspects of social behaviour.

Variation in food abundance, e.g. food depletion, could elicit cascading effects on both physiology and social behaviour. For example, the group size of gre-garious foragers can be reduced if resources are scarce, thus limiting inter-individual feeding interference or scramble competition. Likewise, an increase of social stress may be expected, as a result of either a higher rate of aggression or a limited access to resources per se (Kelley, 1980). In turn, food depletion can have negative effects on both physiology and behaviour. Behavioural responses can lead individuals to divert their attention to a stressful factor, with the suppres- sion or reduction of other activities, such as feeding and reproduction (Reeder \& Krämer, 2005). Although the main role of vigilance behaviour is considered to be an antipredator ploy (Beauchamp, 2015), it could also be an indicator of social stress, leading to trade- offs with foraging behaviour (Berger, 1978; Caraco, 1979; Underwood, 1982). Vigilance could lead to dif- ferent alertness postures by individuals, which imply different potential costs. Foraging individuals can perform either a 'routine vigilance' (i.e. an individual monitors the environment, e.g. Fortin et al., 2004b) or an 'induced vigilance' (i.e. an individual adopts alert- ness postures after an outer stimulus, e.g. Blanchard \& Fritz, 2007). Often, individuals keep on chewing while performing routine vigilance, whereas induced vigilance usually involves an interruption of chewing (Fortin et al., 2004b; Blanchard \& Fritz, 2007). In turn, vigilance postures without chewing are likely to limit the food intake more than those where chewing is not interrupted (Underwood, 1982; Blanchard \& Fritz, 2007). If so, a greater feeding interference between conspecifics might lead to greater levels of vigilance, interfering with foraging and, in turn, determining additional energetic costs to individuals.

Aggressive behaviour is linked to the steroid hor- mone testosterone (Rohwer \& Rohwer, 1978; Creel et al., 1992; Pasch et al., 2011; Martin et al., 2013) which, in turn, can elicit immunosuppression (Folstad \& Karter, 1992; Barnard et al., 1996; Decristophoris et al., 2007). Physiological responses to stress include an increase in the concentration of glucocorticoids or their metabolites (Möstl \& Palme, 2002; Sheriff et al., 2011). Secretion of glucocorticoids by the neuroendo- crine system can reflect the effects of several varia- bles, ranging from climate parameters (Bubenik et al., 1983; Saltz \& White, 1991; Konjević et al., 2011) to behavioural traits (e.g. mating competition; Mooring et al., 2006; Corlatti et al., 2012, 2014; Pavitt et al., 2015, 2016). Long-term (chronic) production of high levels of glucocorticoids can also reduce survival and reproductive success, e.g. through the suppression of the immune function (Sapolsky, 1992; Möstl \& Palme, 2002; but see Boonstra, 2013).

We evaluated the potential cascading effects of resource depletion on key aspects of social behaviour of a mountain-dwelling herbivore, the Apennine chamois, Rupicapra pyrenaica ornata. Recently, changes in the vegetation have been documented on the upper mead- ows of the central Apennines, with a local reduction of pasture quality for mammalian herbivores (Lovari et al., 2014; Corazza et al., 2016). Pasture depletion resulted in a high winter mortality of kids, for the 'vul- nerable' [sensu International Union for Conservation of Nature (IUCN); Herrero et al., 2008] Apennine chamois, in the core of its historical distribution (Lovari et al., 2014; Ferretti et al., 2015; Scornavacca et al., 2016). The negative effects of changes in weather phenology on vegetation grazed by chamois (Ferretti et al., 2018), the spread of unpalatable tall grasses in secondary meadows (Lovari et al., 2014; Corazza et al., 2016) and increased resource exploitation by red deer, Cervus elaphus (Lovari et al., 2014; Ferretti et al., 2015), have been suggested as factors underlying pasture depletion, with subsequent negative effects on population dynamics.

We took advantage of a quasi-experimental situa- tion to test the effects of pasture depletion on levels of grouping behaviour, intraspecific aggression, vigilance and endocrine correlates, by comparing behavioural and physiological indices across areas with different levels of nutritional quality of pasture. We compared two 'poor' areas, i.e. with a lower availability of nutri- tious pasture, with a 'rich' area, i.e. with a greater 
availability of nutritious vegetation (cf. Ferretti etal., 2015; Scornavacca et al., 2016). Evolutionarytheory suggests alternative sets of predictions of the effects of different levels of resource availability/quality on social behaviour, aggression, vigilance and endogenous response to stress. We could expect that feeding interference would be greater in the poor sites than in the rich one, because individuals should increase direct competition for the limited food (hypothesis 1; Sirot, 2000). If so, in the rich area we would expect: the largest groups (prediction 1a); the lowest frequency and intensity of aggression between chamois (prediction $1 b)$; the lowest frequency and duration of vigilance behaviour (prediction 1c); and the lowest levels of faecal cortisol and testosterone metabolites (prediction 1d). Conversely, we could expect higher feeding interference in the rich site than in the poor ones, because individuals should invest more energy in aggressive interactions where resources are not limited (hypoth- esis 2; e.g. Parker, 1974). If so, in the rich area there would be: smaller groups (prediction 2a); the highest frequency and intensity of aggression between chamois (prediction 2b); the highest frequency and duration of vigilance behaviour (prediction 2c); and the highest levels of faecal cortisol and testosterone metabolites (prediction $2 \mathrm{~d}$ ).

\section{MATERIAL AND METHODS}

\section{Study areas and populations}

Our study was conducted in three areas (area P1, upper Val di Rose, $\sim 40$ ha, $1700-1982 \mathrm{~m}$ asl, $41.75000^{\circ} \mathrm{N}$, $13.91666^{\circ} \mathrm{E}$; area P2, upper meadows of Mt. Amaro, $\sim 20$ ha, $1650-1882 \mathrm{~m}$ asl, $41.76666^{\circ} \mathrm{N}, 13.87500^{\circ} \mathrm{E}$; and area R, upper meadows of Mt. Meta, $\sim 30 \mathrm{ha}, 2100-2242 \mathrm{~m}$ asl, $41.69166^{\circ} \mathrm{N}, 13.92500^{\circ} \mathrm{E}$; Fig. 1) within the core of the Abruzzo, Lazio and Molise National Park (ALMNP; central Apennines, Italy). The three sites lie in the same elevational belt (Primi et al., 2016), in the temperate oceanic bioclimate, lower orotemper- ate thermotype and lower/upper humid ombrotype (Pesaresi et al., 2014), and are all covered by grasslands dominated by forbs and/or graminoids. Nevertheless, the three sites have different extents of vegetation cover (Ferretti et al., 2015). Area P1 includes palata- ble graminoids (35.5\%, mainly Festuca spp.), unpalat- able graminoids (24.9\%, Brachypodium genuense) and forb-dominated patches (15.2\%, e.g. Trifolium spp., Ranunculus apenninus, Plantago atrata; Lovari et al., 2014). Area P2 includes palatable graminoids (57.7\%, mainly Festuca spp.), unpalatable graminoids (11.1\%,

B. genuense) and forb-dominated patches (15.1\%, e.g. Anthyllis vulneraria, Medicago lupulina, Hippocrepis comosa). Area $\mathrm{R}$ includes forb-dominated patches (24.5\%, e.g. Trifolium spp., A. vulneraria), palatable graminoids (38.7\%, mainly Festuca spp.) and unpalat- able graminoids $(1.0 \%$, B. genuense). Rocks/screes with sparse vegetation are also present in each site (area P1, 25\%; area P2, 15\%; area R, 36\%; Ferretti et al., 2015).

High-quality, cold-adapted forb patches domi- nated by Trifolium thalii and other legumes are the most nutritious food resources for chamois (Ferrari et al., 1988; Lovari et al., 2014), as well as the most selected ones (Ferrari et al., 1988; Ferretti et al., 2014). Forb-dominated patches are more abundant in area R $(24.5 \%$ of cover) than in areas P1 and P2 ( $15 \%$ of cover), whereas patches dominated by unpal- atable $B$. genuense are widespread in areas P1 and P2 ( 11-25\%) but very rare in area $\mathrm{R}(\sim 1 \%)$ (Ferretti et al., 2015). In female chamois, the volume of forbs in the diet (P1, 40\%; P2, 47\%; R, 60\%; Ferretti et al., 2015), the volume of nutritious plants in the diet (P1, 5.5\%; P2, 6\%; R, 9\%; Ferretti et al., 2015) and feeding efficacy, i.e. number of bites per step per minute (P1, 8; P2, 12; R, 14; Ferretti et al., 2015), were the greatest in area $R$. In contrast, the volume of graminoids in the diet (P1, 55\%; P2, 45\%; $R, \sim 35 \%$; Ferretti et al., 2015) was the lowest in area $R$, suggest- ing that female chamois were better fed in area R. In turn, frequency/intensity of suckling behaviour and survival of chamois kids were greater in area R than in areas P1 and P2 (Ferretti et al., 2015; Scornavacca et al., 2016).

A great density of wild ungulates, i.e. red deer (Ferretti et al., 2015), wild boar, Sus scrofa (Fabbri et al., 1983), and, to a much lesser extent, roe deer, Capreolus capreolus (Latini et al., 2015), was present in the core area of the ALMNP. Although red deer were present at the same elevation as chamois in areas P1 and P2, they were not in area R, where they inhab-ited lower elevations than chamois (Lovari et al., 2014; Ferretti et al., 2015). Thus, grasslands of areas $P 1$ and $P 2$, but not those of area $R$, were grazed by red deer at high densities, with additional negative effects on vegetation cover and food availability for chamois (Ferretti et al., 2015). In turn, the pasture quality and quantity differed greatly amongst sites, being richer in area $R$ than in areas $\mathrm{P} 1$ and $\mathrm{P} 2$. 
In the warm months, mixed groups of female Apennine chamois, yearlings and kids graze on alpine meadows, whereas males are solitary, living in forests at lower elevations (except during the rut in November and December, when they join the groups of females and juveniles) (Lovari \& Cosentino, 1986). No chamois was artificially marked. A minimum of 32 (in 2014) and 21 (in 2015) chamois (i.e. the maximal number of indi- viduals observed at the same time) were present in groups with females, yearlings and kids in area P1; 35 (in 2014) and 29 (in 2015) individuals were present in area P2, and 69 (in 2014) and 78 (in 2015) individuals were present in area R. During the last decade, cham- ois numbers have decreased in areas P1 and P2 (>50\% decrease in area P1 and $>20 \%$ decrease in area P2; Ferretti et al., 2015), because of heavy winter mortal- ity of kids, which was related to lower maternal care and, ultimately, to lower food availability for females (Lovari et al., 2014; Ferretti et al., 2015; Scornavacca et al., 2016). Conversely, an increase in the population of chamois was recorded in area R, where only five or six males were present in 1975s-1980s, with no mixed group of females, yearlings and kids (S.L., personal observations).

Female ungulates are philopatric, and their emi- gration is an infrequent event (Bocci \& Lovari, 2011; northern chamois $R$. rupicapra: Loison et al., 1999, 2008). In turn, female chamois with morphologically distinct features (e.g. horn morphology, a broken horn, scars; Lovari \& Rolando, 2004: 78) did not appear to move between our study sites. Moreover, preliminary data based on VHF/GPS radio-tracking support the local herd/site fidelity of female chamois (Latini et al., 2013).

In ALMNP, potential predators of chamois are grey wolf, Canis lupus, Apennine brown bear, Ursus arc- tos marsicanus, and golden eagle, Aquila chrysaetos, although predation on chamois was negligible $(<2 \%$ for wolf, Grottoli, 2011; Patalano \& Lovari, 1993; 0.05\% for brown bear, Ciucci et al., 2014; uncommon and restricted mainly to kids, for golden eagle, Scornavacca \& Brunetti, 2015). It was assumed that predation pres- sure on chamois was comparably scarce across all three areas and that the three sites did not differ regarding accessibility to predators, which visited all our study areas (our observations; wolf, Mancinelli et al., 2018; brown bear, Maiorano et al., 2015; golden eagle, Artese et al., 2017).

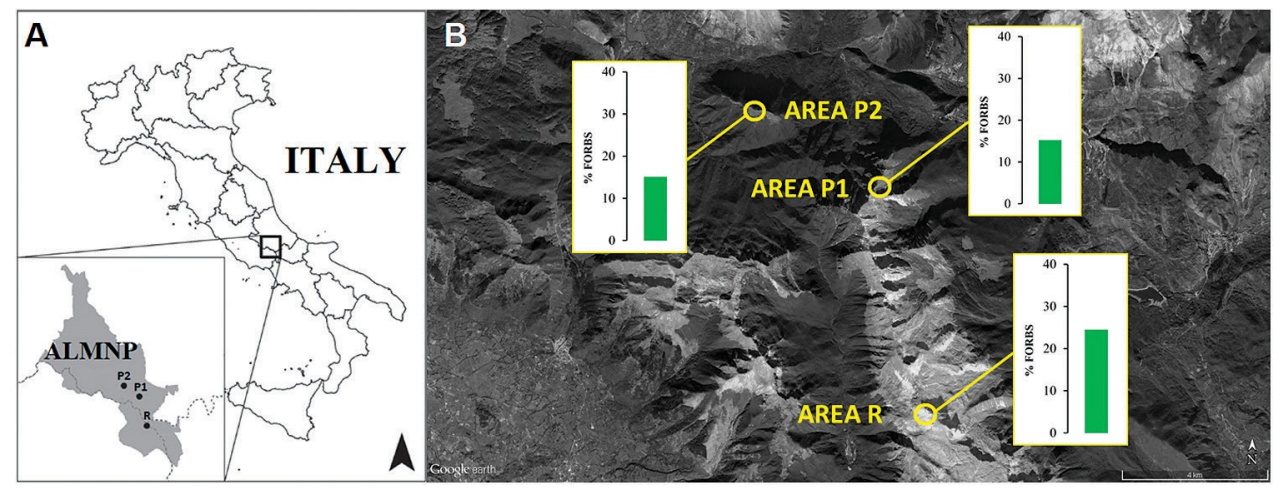

Figure 1. A, locations of study areas within the Abruzzo, Lazio and Molise National Park (ALMNP). B, relevant availability of nutritious pasture for chamois. Map data: Google, Digital Globe.

\section{Behavioural data}

Behavioural observations were conducted from July to October, in 2014 and 2015, from dawn to dusk. We performed $6-8 \mathrm{~h}$ of observations each day, for at least 7-8 days at each site during each month. We made an effort to balance sampling across sites, months and times of the day. Chamois were observed using binocu- lars (Nikon $10 \times 30$, Zeiss $15 \times 70$ ) or spotting scopes (Nikon 20-60x), at a distance of 50-200 m, depending on the terrain and range of vision. In our study area, chamois were habituated and could be approached up to $30 \mathrm{~m}$ (Bruno \& Lovari, 1989; S. L., unpublished data) without showing alert behaviour (staring in the direc- tion of the observer or orientating their ears to him or her, and raising the tail as a sign of alarm; Lovari, 1985). However, we avoided recording data whenever we felt that the animals were reacting to our presence (cf. Winnie \& Creel, 2007). 
Our hypotheses have been focused on females, because: (1) pasture quality is particularly important to nursing females and weaning kids, which in turn are key drivers of population dynamics; and (2) except during the rut, most adult males are solitary, living on steep, forested slopes, thus escaping observational opportunities on a regular basis. Aggressive interac-tions among females ( 2 years old) were assessed through continuous focal group sampling (Altmann, 1974), by two or three observers, on foraging groups of females, yearlings and kids. Amongst group-living species, aggressive interactions should be relatively rare events within the overall time budget (e.g. birds: Caraco, 1979; mammals: Molvar \& Bowyer, 1994). Dawkins (2007: 93) suggests longer sampling bouts to record infrequent events. Thus, we observed each focal group for $30 \mathrm{~min}$, depending on group movements and visibility. Whenever possible, when the group did not split, we continued observing the focal group up to a maximum of $6 \mathrm{~h}$. Each focal group observation bout was divided into 5 min sampling periods, to record variation in group size and structure (number of adult and subadult females; number of yearlings; number of kids; number of adult and subadult males), which were assessed by instantaneous scan sampling (Altmann, 1974). We considered a group as at least 2 animals staying in sight and less than $40 \mathrm{~m}$ apart from each other at the time of observation (e.g. Krämer, 1969; Bruno \& Lovari, 1989).

We recorded all the occurrences of aggressive interac- tions performed between grazing females during each 5 min sampling period using an mp3 dictaphone. For each aggression event, we recorded the date and time (in hours and minutes), age class of the opponents, type of interaction and behavioural patterns used by each individual. Four age classes were assessed according to Lovari (1985): subadult, i.e. 2-3 years old; 4-5 years old; 6-8 years old; and 9 years old. The type of inter-action was defined as a single aggression (a dominance pattern followed by an immediate submission/escape by the opponent) or a sequence (a series of consecutive dominance behaviour patterns performed by both oppo- nents). The latter case implied that the attacked indi- vidual reacted to the aggressor, thus we considered it as an escalation. Dominance and submissive behaviour patterns (Lovari, 1985) performed by female chamois were recorded. Dominance patterns include both indi- rect and direct forms of aggression to intimidate/dis- place rivals (Lovari, 1985). Indirect forms involve visual dominance postures (Lovari, 1985). Direct threats, such as approaches/chases, are the least ritualized and may include attempts at physical contact, although this is rare (Locati \& Lovari, 1990). Submissive patterns include withdrawal and several ritualized, submissive postures, e.g. low stretch (Lovari, 1985). We excluded vocally based patterns because of the complexity in their detection and interpretation (Lovari, 1985). Dominance behaviour patterns of female chamois were divided into direct and indirect forms of aggres- sion (hereafter threats and displays, respectively; e.g. Walther, 1974; Schaller, 1977), to evaluate the inten- sity of interference. Threats were considered more intense, less ritualized forms of aggression than dis- plays (Walther, 1974; Schaller, 1977; Lovari et al., 2015; in Apennine chamois: Lovari, 1985).

Vigilance behaviour was assessed by continuous focal animal sampling (Altmann, 1974), by two or three observers, on foraging females. Given that vigi- lance events are more frequent than agonistic events (e.g. birds: Caraco, 1979; mammals: Molvar \& Bowyer, 1994), we used shorter sampling periods to record them (Dawkins, 2007: 93). Observations were con-ducted in 10 min bouts (e.g. Favreau et al., 2018). Each bout was divided into 1 minute sampling periods, to record position and variation of group size and struc- ture. Group size and structure (number of adult and subadult females; number of yearlings; number of kids; number of adult and subadult males) and the distance to the nearest cliff (i.e. distance from escape terrain: 0-25, 25-75 or $>75 \mathrm{~m}$ ) were assessed by instantaneous scan sampling (Altmann, 1974). We recorded the num- ber of head lifts performed by a female chamois during each $1 \mathrm{~min}$ sampling interval. The age class of the focal female was assessed as above. We considered a head lift when a female interrupted grazing and raised her head above her shoulders while scanning (e.g. Lipetz \& Bekoff, 1982; Bruno \& Lovari, 1989). For each head lift, we recorded date, time (hours and minutes), dur- ation (in seconds) and type: chewing (the individual keeps on chewing while scanning), no chewing (the individual does not chew while scanning) or indeter- minate (we could not see the mouth of the individual). Chewing was considered a clue to evaluate the cost of vigilance; head lifts where individuals do not chew are expected to interfere with foraging processes more than those where chewing continues (see Introduction; Underwood, 1982; Fortin et al., 2004a). We avoided recording vigilance behaviour of the same individual on the same day; we observed chamois that could be distinguished by their respective positions on the slope (Frid, 1997), while another observer monitored those that had already been sampled. Small morphological differences (horn patterns, e.g. broken horns; coat/colour features, e.g. scars/spots; Lovari \& Rolando 2004: 78) also helped to reduce the probability of recording data from the 
same individual repeatedly on the same day (Lovari et al., 2014; Ferretti et al., 2014; 2015).

\section{Endocrine data}

The assessment of faecal hormone metabolites is a non- invasive tool, which provides unbiased results because the animal is not stressed by handling (Millspaugh \& Washburn, 2004; Sheriff et al., 2011). In addition, it can provide reliable information on basal endocrine levels of wild species, representative of long-term lev- els (Millspaugh \& Washburn, 2004; Sheriff et al., 2010). Faecal samples of female ( 2 years old) and year- ling chamois were collected from July to October 2015, to assess contents of faecal androgen metabolites and faecal cortisol metabolites as hormonal indicators of aggressiveness and stress, respectively (cf. south- ern chamois: Dalmau et al., 2007; northern chamois: Corlatti et al., 2012, 2014; Zwijacz-Kozica et al., 2013; Hadinger et al., 2015). We observed grazing chamois and collected fresh faeces immediately after we saw a defecation event, at a distance of up to $\sim 50 \mathrm{~m}$. We put each sample into a plastic bag and stored it in a portable freezer box, which prevented changes of steroids attributable to the air temperature and immunoreaction of metabolites (Möstl et al., 1999). The date, time (in hours and minutes) and age class (yearling, subadult female or adult female) of the chamois were recorded. Faecal samples were frozen at

$-20^{\circ} \mathrm{C}$ immediately after returning the field, no later than $10 \mathrm{~h}$ from collection (Ezenwa et al., 2012; Corlatti et al., 2012, 2014). We tried to balance faecal sample collection by the month, time of day and chamois age class. We avoided the repeated collection of samples from the same individual on the same day.

Extraction and determination of faecal steroids were conducted as reported by Pecorella et al. (2016) for fallow deer, Dama dama (see Determination of fecal steroids; Supporting Information).

\section{Statistical analyses}

Focal group bouts that lasted $<15 \mathrm{~min}$ and focal ani- mal bouts that lasted $<5 \mathrm{~min}$ were discarded from the analyses. Short bouts occurred when the focal group or individual moved away from our sight, or when poor weather (e.g. fog) limited our range of vision. Overall, we analysed 202 focal group bouts to assess grouping patterns and female-female aggression ( $\sim 543 \mathrm{~h}$ of observa- tion; mean $\pm \mathrm{SE}: 2.7 \pm 0.1 \mathrm{~h}$ per group), 851 focal animal bouts to assess female vigilance ( $120 \mathrm{~h}$ of observation; mean $\pm \mathrm{SE}: 8.5 \pm 0.1 \mathrm{~min}$ per individual) and 116 faecal samples (area P1, $N=5$; area P2, $N=15$; area $\mathrm{R}, N=96$ samples) of female and yearling chamois to assess endocrine correlates. Collection of faecal samples in poor areas was limited by the low population size of chamois. Owing to the the small sample sizes at sites P1 and P2,

i.e. sites with lower pasture quality, we pooled them for comparisons with area R, i.e. the site with greater pasture quality, to assess endocrine differences.

We investigated differences in patterns of chamois social behaviour (grouping, aggression and vigilance) and hormone levels across study areas through gen- eralized linear models and generalized linear mixed models (GLMs and GLMMs, respectively; Zuur et al., 2009). Statistical analyses were conducted using the information-theoretic approach (Burnham \& Anderson, 2002), by evaluating multiple competing a priori hypotheses, for each indicator. In addition to food availability, previous studies also identified influ- encing factors of grouping, aggression, vigilance and hormone levels (Supporting Information, Table S1). We could not discard, in advance, any combination of these variables, because all the relevant hypotheses could be meaningful biologically. Thus, we first performed a model selection (see Model selection; Supporting Information), for each indicator, to rank all possible models, because each of them could represent a dif- ferent plausible a priori hypothesis. We modelled ten different response variables separately (Supporting Information Table S2). Error distributions and link functions used to model each response variable are listed in the Supporting Information (Table S2).

For each indicator, the global model included all the biologically meaningful fixed effects (Supporting Information Tables S1 and S2). We considered the site as a predictor to evaluate the role of pasture availability (reference category:area P2, for behavioural data; areas P1 + P2, for endocrine data). In addition, we included a set of different controlling predictors, depending on the indicator (see Fixed effects in global models; Supporting Information). Although we minimized pseudoreplica- tion of collected data (cf. above), our analyses required conservative assumptions because of unmarked ani- mals. In turn, we accounted for the effects of each group, 
regarding grouping patterns and aggression, and each foraging individual, regarding vigilance. To this end, nested random effects within sites were allowed in each model, depending on the indicator (see Random effects; Supporting Information). Multicollinearityamongst covariates was tested for each full model by calculating the variance inflation factor (VIF) for all the predictors, through the R package car (Fox \& Weisberg, 2011). All VIF values were less than two, indicating no multicol- linearity (Zuur et al., 2009).

For each response variable, the coefficient of predic- tors, $95 \%$ confidence intervals and variance of ran- dom effects were estimated for the top-ranked model. The significance of predictors was assessed by check- ing whether $95 \%$ confidence intervals included zero. Validation of the best models was made by visual inspection of residual patterns (Zuur et al., 2009). Model selection, GLMs and GLMMs were performed through the $\mathrm{R}$ packages MuMIn (Bartoń, 2012), stats (R Core Team, 2013), VGAM (Yee, 2015) and glm- mADMB (Bolker et al., 2012).

\section{RESULTS}

\section{Grouping patterns}

Groups included a greater number of chamois in area $\mathrm{R}$, where the mean group size was more than twice greater than in the other areas (Table 1a; Fig. 2A). The proportion of immature individuals (i.e. kids, yearlings and subadults) was $\sim 40 \%$ greater in area $\mathrm{R}$ compared with the other sites (Table $1 \mathrm{~b}$; Fig. $2 \mathrm{~B}$ ). Grouping phenology was also influenced by the year and time of day (Table 1a,1b).

\section{Intraspecific Aggression}

The aggression rate between females was the lowest in area $\mathrm{R}$ (Table 1c). On average, in area $\mathrm{R}$ this index was lower by $\sim 25 \%$ and $\sim 40 \%$ compared with areas $\mathrm{P} 1$ and $\mathrm{P} 2$, respectively (Fig. $2 \mathrm{C}$ ). The aggression rate between females was also influenced by the number of females in the group, the date and the time of day (Table 1c). We found an effect of site on aggression intensity, i.e. the probability to perform a threat (Table $1 \mathrm{~d}$ ); in areas $\mathrm{P} 1$ and $\mathrm{P} 2$, the occurrence of direct forms of aggression was more frequent, although weakly, than in area $\mathrm{R}$ (Table 1d). This indicator was also influenced by the date, time of day, year, age class of the opponents and type of interaction (Table 1d).

Vigilance Behaviour

For all behavioural indicators of vigilance, the effect of site was included in selected models, except for head lift rate (Supporting Information, Table S3). Although the time spent in vigilance did not vary among sites (Table $2 \mathrm{~d}$ ), the probability of occurrence of costly head lifts and the mean duration of head lifts were the low- est in area $R$ (Fig. 3A, 3B; Table 2b,2c). Overall, behav- ioural indices of alertness were also influenced by date, year, time of day, age class, distance to the nearest cliff and percentage of costly head lifts, depending on the index (Table 2). The effect of group size on vigilance, when present, was conflicting. Head lift rate decreased with increasing group size (Table 2a). Conversely, head lift cost and duration showed a positive relationship with group size (Table $2 \mathrm{c}, 2 \mathrm{~d}$ ). Hormone levels

Levels of faecal androgen metabolites were higher in areas P1 + P2 than in area R (Fig. 4A; Table 3a). Likewise, levels of faecal cortisol metabolites were also higher in areas P1 + P2 than in area R (Fig. 4B; Table 3b). Faecal hormone metabolite levels were also influenced by age class, date and time of the day (Table 3). 

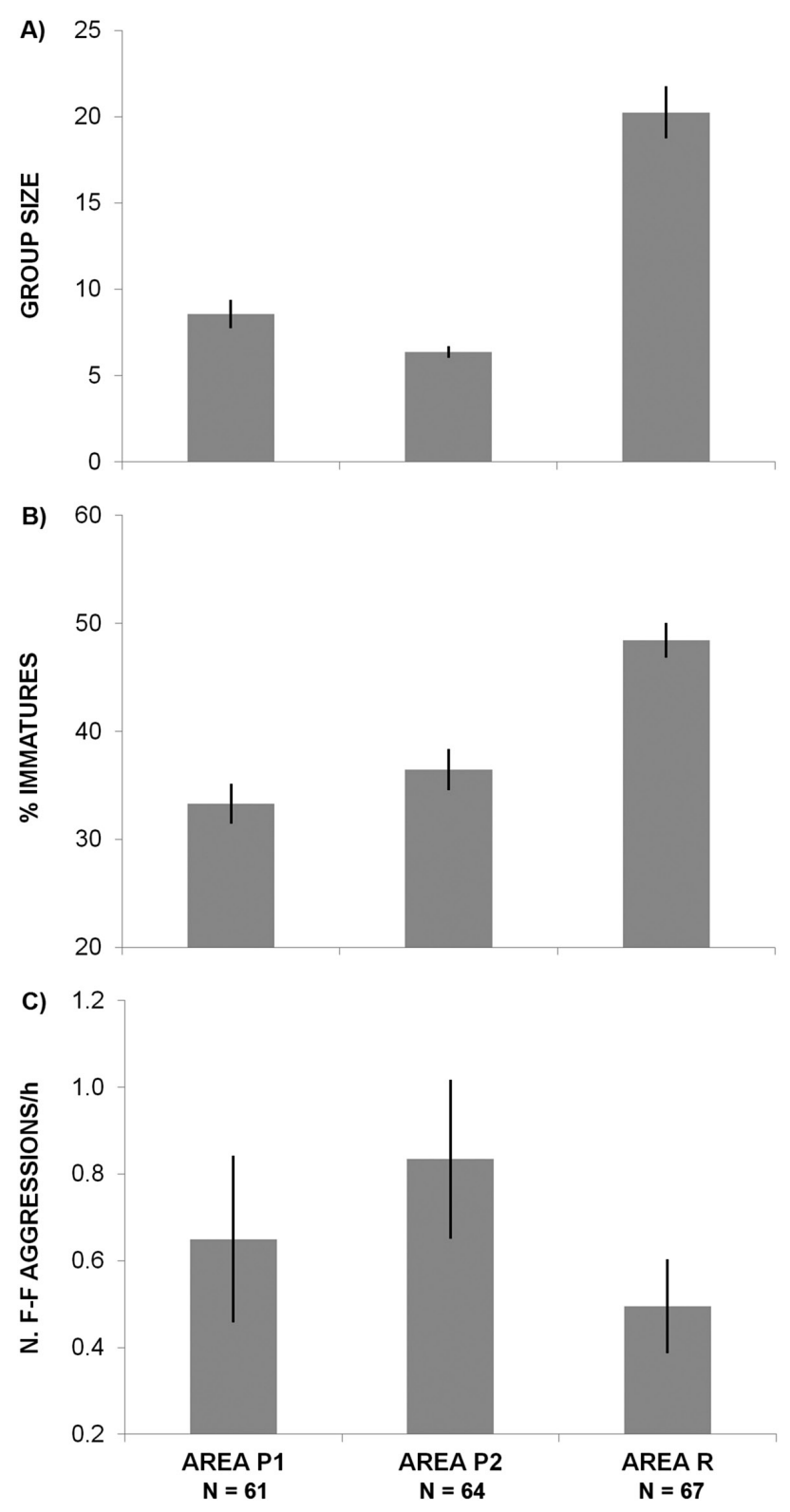

Figure 2. A-C, mean group size (A), percentage of imma- ture animals (B) and rate of female-female aggression (nor- malized by the number of females in the group; $C$ ), at each site. Error bars, $S E ; N$, number of focal group bouts.

Table 1. Parameters estimated from the top-ranked models on grouping and aggressive behaviour

\begin{tabular}{llclc}
\hline Indicator & Predictor & \multicolumn{1}{c}{$B$} & \multicolumn{1}{l}{$\mathrm{SE}$} & \multicolumn{1}{c}{$95 \% \mathrm{Cl}$} \\
\hline (a) Group size & Intercept & 1.8154 & 0.3266 & $1.1752 ;$ \\
(focal group) variance $=0.3802$ & Site (area P1) & $\mathbf{0 . 2 2 9 9}$ & $\mathbf{0 . 1 1 3 5}$ & $\mathbf{0 . 0 0 7 4 ;}$ \\
& & & & $\mathbf{0 . 4 5 2 3 *}$ \\
(sampling interval) variance $=0.0010$ & Site (area R) & $\mathbf{1 . 1 2 7 9}$ & $\mathbf{0 . 1 0 7 3}$ & $\mathbf{0 . 9 1 7 7 ;}$ \\
& & & & $\mathbf{1 . 3 3 8 1 *}$ \\
& Date & 0.0014 & 0.0012 & $-0.0010 ; 0.0038$ \\
& Time & -0.0587 & 0.0188 & $-0.0956 ;-0.0218^{*}$ \\
& Time & 0.0030 & 0.0008 & $0.0014 ;$ \\
& Year (2015) & -0.3376 & 0.0904 & $-0.0045^{*}$ \\
(b) Immature animals in group & Intercept & $-0.1604^{*}$ \\
& & & & $-1.2006 ;-0.3983^{*}$
\end{tabular}




\begin{tabular}{|c|c|c|c|c|}
\hline (focal group) variance $=1.7260$ & Site (area P1) & -0.1123 & 0.2395 & $\begin{array}{l}-0.5818 \\
0.3571\end{array}$ \\
\hline \multirow[t]{3}{*}{ (sampling interval) variance $=0.0228$} & Site (area $\mathbf{R})$ & 0.9581 & 0.2274 & $\begin{array}{l}0.5125 \\
1.4038 *\end{array}$ \\
\hline & Time $^{<}$ & -0.0016 & 0.0005 & $-0.0026 ;-0.0005^{*}$ \\
\hline & Year (2015) & -0.3317 & 0.1917 & $-0.7074 ; 0.0440$ \\
\hline (c) Aggression rate & Intercept & -1.0628 & 0.4887 & $-2.0206 ;-0.1049 *$ \\
\hline (focal group) variance $=0.6276$ & Site (area P1) & -0.1576 & 0.1761 & $\begin{array}{l}-0.5028 \\
0.1875\end{array}$ \\
\hline \multirow[t]{4}{*}{ (sampling interval) variance $=0.0008$} & Site (area R) & -0.4173 & 0.1818 & $-0.7736 ;-0.0611 *$ \\
\hline & Date & -0.0050 & 0.0020 & $-0.0088 ;-0.0011^{*}$ \\
\hline & Time $^{2}$ & 0.0016 & 0.0008 & $\begin{array}{l}0.0001 ; \\
0.0032 *\end{array}$ \\
\hline & Number of females in group & 0.0912 & 0.0085 & $\begin{array}{l}0.0745 \\
0.1079 *\end{array}$ \\
\hline \multirow{10}{*}{$\begin{array}{l}\text { (d) Aggression intensity } \\
\text { (focal group) variance }=109.8000\end{array}$} & Intercept & -18.3874 & 6.3085 & $-30.6890 ;-6.0858^{*}$ \\
\hline & Site (area P1) & 3.0403 & 1.2832 & $\begin{array}{l}0.5381 ; \\
5.5425 *\end{array}$ \\
\hline & Site (area R) & -1.7294 & 1.2576 & $\begin{array}{l}-4.1817 \\
0.7229\end{array}$ \\
\hline & Date & 0.0219 & 0.0283 & $-0.0333 ; 0.0771$ \\
\hline & Time & 4.5876 & 0.9061 & $\begin{array}{l}2.8207 ; \\
6.3545^{*}\end{array}$ \\
\hline & Time $^{2}$ & -0.2039 & 0.0382 & $-0.2784 ;-0.1294^{*}$ \\
\hline & Aggression type (sequence) & -11.8629 & 2.2038 & $-16.1603 ;-7.5655^{*}$ \\
\hline & Sender age class ( $4-5$ years) & 7.5718 & 1.6294 & $4.3945 ; 10.7491^{*}$ \\
\hline & Sender age class ( $6-8$ years) & 5.9469 & 1.3551 & $\begin{array}{l}\text { 3.3045; } \\
8.5893^{*}\end{array}$ \\
\hline & Sender age class ( 9 years) & 9.3455 & 1.7029 & $6.0249 ; 12.6661^{*}$ \\
\hline
\end{tabular}

Variance of random factors is also shown. The reference categories of categorical predictors are as follows: area P2 (for site); 2014 (for year); single aggression (for aggression type), 2-3 years (for age class); and younger (for relative age of the recipient). Effect of site is shown in bold. Abbreviations: $B$, coefficient; SE, standard error; $95 \%$ $\mathrm{Cl}, 95 \%$ confidence interval. Asterisks indicate the confidence intervals that do not include zero.

Table 2. Parameters estimated from the top-ranked models on vigilance behaviour; for generalized linear mixed models, variance of random factors is also shown

\begin{tabular}{llrrr}
\hline Indicator & Predictor & $B$ & SE & $95 \% \mathrm{Cl}$ \\
\hline (a) Vigilance rate & Intercept & 0.3302 & 0.2650 & $-0.1892 ; 0.8496$ \\
(focal individual) variance $=0.4164$ & Date & -0.0050 & 0.0010 & $-0.0069 ;-0.0031^{*}$ \\
(sampling interval) variance $<0.0001$ & Time & 0.0011 & 0.0004 & $0.0003 ; 0.0019^{*}$ \\
& Year (2015) & -0.6668 & 0.0635 & $-0.7912 ;-0.5424$ \\
& Age class (4-5 years) & 0.2882 & 0.1345 & $0.0246 ; 0.5518^{*}$ \\
& Age class (6-8 years) & 0.1692 & 0.1240 & $-0.0739 ; 0.4123$ \\
& Age class ( 9 years) & 0.0884 & 0.1216 & $-0.1499 ; 0.3267$ \\
& Cliff distance (0-25 m) & -0.0913 & 0.0735 & $-0.2353 ; 0.0527$ \\
& Cliff distance (> 75 m) & 0.1058 & 0.0848 & $-0.0604 ; 0.2720$ \\
(b) Vigilance cost & Group size & -0.0103 & 0.0022 & $-0.0146 ;-0.0060^{*}$ \\
(focal individual) variance $=0.0775$ & Intercept & 0.0578 & 0.1980 & $-0.3302 ; 0.4458$ \\
& Site (area P1) & $\mathbf{0 . 0 9 1 9}$ & $\mathbf{0 . 0 3 5 0}$ & $\mathbf{0 . 0 2 3 2} ;$ \\
& Site (area R) & $-\mathbf{0 . 1 6 0 6}$ \\
& Date & $-\mathbf{0 . 1 1 3 0}$ & $\mathbf{0 . 0 4 2 6}$ & $\mathbf{- 0 . 1 9 6 4 ;}$ \\
& & $-0.0295^{*}$
\end{tabular}




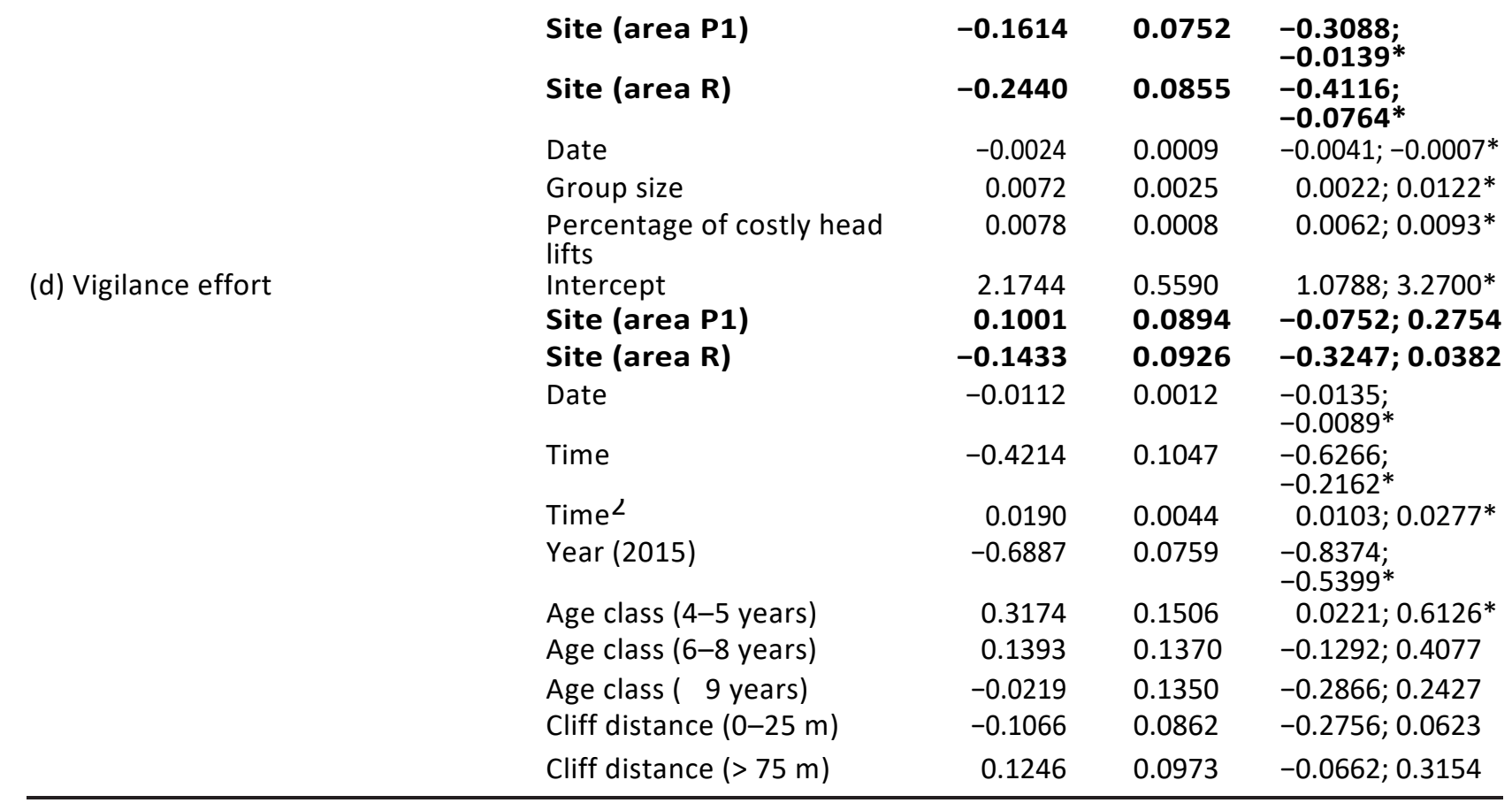

The reference categories of categorical predictors are as follows: area P2 (for site); 2014 (for year); 2-3 years (for age class); and 25-75 $\mathrm{m}$ (for cliff distance). Effect of site, when present, is shown in bold. Abbreviations: $B$, coefficient; $\mathrm{SE}$, standard error; $95 \% \mathrm{Cl}, 95 \%$ confidence interval. Asterisks indicate the confidence intervals that do not include zero.

Figure 3. A, B, mean percentage of costly head lifts (A) and mean duration of head lifts (B), both normalized by group size, at each site. Error bars, SE; $N$, number of focal animal bouts in which chewing/non-chewing activity was recorded.

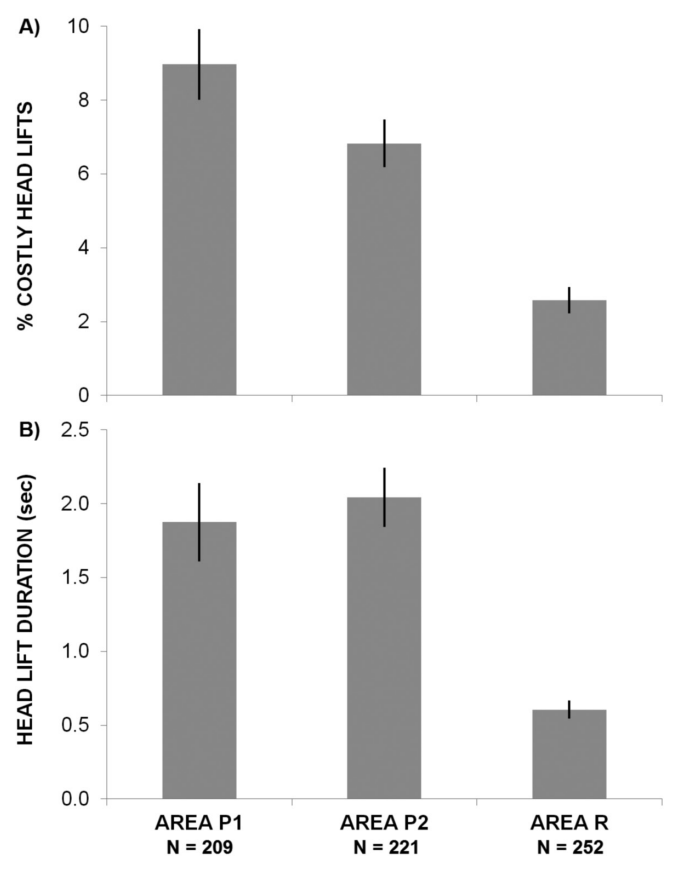




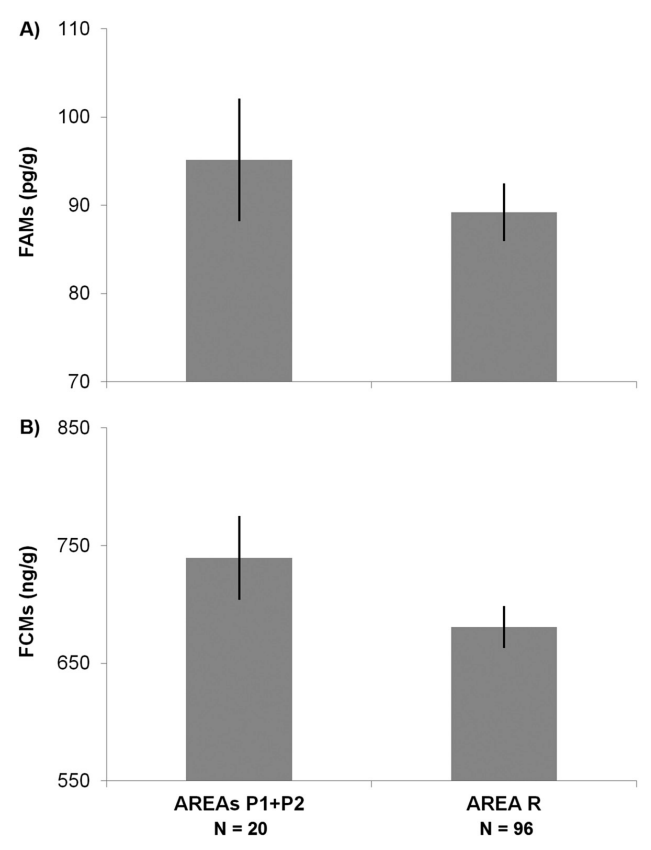

Figure 4. A, B, mean concentration of faecal androgen metabolites (FAMs; $A$ ) and faecal cortisol metabolites (FCMs; B), at each site. Error bars, SE; $N$, number of faecal samples.

Table 3. Parameters estimated from the top-ranked models on hormone levels

\begin{tabular}{|c|c|c|c|c|}
\hline Indicator & Predictor & $B$ & SE & $95 \% \mathrm{Cl}$ \\
\hline \multirow[t]{5}{*}{ (a) Testosterone $\left(\mathrm{pg} \mathrm{g}^{-1}\right)$} & Intercept & 53.2105 & 3.1390 & $47.3808 ; 59.3961^{*}$ \\
\hline & Site (area R) & -5.2497 & 2.5279 & $\begin{array}{l}-10.4578 \\
-0.5150 *\end{array}$ \\
\hline & Time $^{2}$ & 0.0228 & 0.0128 & $-0.0017 ; 0.0477$ \\
\hline & Age class (subadult) & 3.9488 & 1.9100 & $0.2096 ; 7.7534^{*}$ \\
\hline & Age class (adult) & 53.2376 & 2.0621 & 49.2167; 57.3019* \\
\hline \multirow[t]{7}{*}{ (b) Cortisol $\left(\mathrm{ng} \mathrm{g}^{-1}\right)$} & Intercept & 989.8371 & 158.1120 & $\begin{array}{l}\text { 679.9432; } \\
1299.7310^{*}\end{array}$ \\
\hline & Site (area R) & $\begin{array}{c}-60.048 \\
7\end{array}$ & 25.8718 & $\begin{array}{l}-110.7564 \\
-9.3409 *\end{array}$ \\
\hline & Date & -0.7984 & 0.3366 & $-1.4581 ;-0.1386^{*}$ \\
\hline & Time & -40.9135 & 27.3910 & $-94.5988 ; 12.7719$ \\
\hline & Time $^{2}$ & 1.9612 & 1.1926 & $-0.3763 ; 4.2986$ \\
\hline & Age class (subadult) & -94.8883 & 35.3386 & $\begin{array}{l}-164.1508 \\
-25.6259 *\end{array}$ \\
\hline & Age class (adult) & 227.2857 & 27.4482 & $\begin{array}{l}\text { 173.4882; } \\
281.0831^{*}\end{array}$ \\
\hline
\end{tabular}

The reference categories of categorical predictors are as follows: area P1 + P2 (for site); and yearling (for age class). Effect of site is shown in bold. Abbreviations: $B$, coefficient; SE, standard error; $95 \% \mathrm{Cl}, 95 \%$ confidence interval. Asterisks indicate the confidence intervals that do not include zero.

\section{DISCUSSION}

For herbivores living in seasonal environments, the availability of high-quality resources in the warm months plays a key role in influencing food intake, body growth, weaning and survival of offspring, in turn affecting population dynamics (Gaillard et al., 2000; Côté \& Festa-Bianchet, 2001; Pettorelli et al., 2007; Therrien et al., 2007; Ferretti et al., 2015). Our results suggest that depletion of forage can addition- ally 
influence the intraspecific social behaviour of individuals, by increasing aggression and vigilance, and their endocrine correlates, in turn agreeing with competition theory (hypothesis 1).

The smallest chamois groups were observed in poor areas (i.e. areas P1 and P2), where large groups were frequently observed in past decades, when pasture was rich (i.e. up to 60 or 30 individuals, respectively; S.L., personal observations). In these sites, pasture depletion has ultimately led to a sharp decrease of chamois numbers, in the last decade, through its effects on foraging behaviour, maternal care and sur- vival of kids (Lovari et al., 2014; Ferretti et al., 2015; Scornavacca et al., 2016). The group size of cham- ois may increase with population density (Pépin \& Gerard, 2008). If so, high mortality of kids and popu- lation decrease (Ferretti et al., 2015) could have led to a reduction of both group size and the proportion of younger individuals in the groups. The group size of chamois is expected to increase with the nutritional quality of pasture (Ferrari et al., 1988; Bruno \& Lovari, 1989); in turn, depleted food patches should support smaller groups (cf. Chirichella et al., 2015, in north- ern chamois). Furthermore, individuals may tend to avoid feeding interference by aggregating in smaller groups (cf. Molvar \& Bowyer, 1994). In all these cases, resource availability should be regarded as the ultim- ate determinant of the observed patterns of grouping behaviour (our prediction 1a).

Group-living herbivores coexist by balancing the costs and benefits of gregariousness, e.g. through a trade-off between food intake, vigilance and recip- rocal aggressiveness (e.g. Molvar \& Bowyer, 1994). Staying in larger groups allows individuals to benefit from group vigilance as antipredatory behaviour, i.e. reduced probability of being the victim of a predatory attack, without decreasing their feeding efficiency (e.g. Pulliam, 1973; Berger, 1978). Nevertheless, feeding interference can be greater in larger groups (Molvar \& Bowyer, 1994; Sirot, 2000). Accordingly, our results showed that the rate of aggression between female chamois increased as the number of females in a group increased, suggesting that individuals may trade-off higher safety against greater intraspecific competi- tion. One could have expected that the aggression rate between chamois might be higher in area $\mathrm{R}$, because group size was the largest in that site, in turn determining a greater probability of interaction with other individuals. Conversely, the frequency and the intensity (i.e. the ratio of threats to displays) of aggression between female chamois were greater in areas with the lowest pasture quality than in the rich one. These results confirm our prediction (1b) that a decrease in available food resources might lead to an increase in the level of aggressiveness between individuals; thus, interference competition enhanced aggres- sion, where resources were scarce. Our results are in agreement with the model proposed by Sirot (2000), which predicted that aggression would rise when food resources are limited, as an evolutionary stable strategy.

Several indicators of vigilance were higher in the poor areas than in the rich one, providing support to our prediction (1c). In gregarious animals, foraging individuals are expected to increase their scanning rate according to decreasing group size and higher predation risk (Lima, 1987; Roberts, 1996; Lima et al., 1999; Barbosa, 2002). Local large predators (grey wolf, brown bear and golden eagle) visit all our study areas (our observations; Maiorano et al., 2015; Artese et al., 2017; Mancinelli et al., 2018). Nevertheless, predation on chamois is negligible (cf. Material and Methods), most probably because of the steep and rugged habi- tat used by these ungulates and their antipredatory behaviour (Scornavacca \& Brunetti, 2015; Baruzzi et al., 2017; Šprem et al., 2015), suggesting a low pre- dation risk, in all sites. Ferretti et al. (2015) showed that the bite rate, i.e. a clue for chamois foraging effi- ciency, was the lowest in areas P1 and P2 because of pasture depletion (but see Puorger et al., 2018, for northern chamois). Feeding efficiency should be traded off by vigilance (Caraco, 1979; Ruckstuhl et al., 2003; Fortin et al., 2004b). If so, in poor areas, chamois would be expected to reduce their scanning behaviour to allocate more time in feeding activities (Beauchamp \& Ruxton, 2003; Ruckstuhl et al., 2003). Although the head lift rate and time spent in vigilance by female chamois did not differ across sites, the cost of vigi- lance, i.e. the interruption of chewing while scanning and the mean duration of head lifts, were greater in poor areas and tended to increase with group size. The mean head lift duration of individuals also increased with the proportion of costly head lifts. Costly, i.e. 'induced' vigilance, is usually performed by individu- als reacting to an outer stimulus (e.g. Blanchard \& Fritz, 2007) which, in group-living species, can be rep- resented by the proximity of a potential competitor (see also McDougall \& Ruckstuhl, 2018). These results strongly suggest that females grazing in areas P1 and P2 were disturbed more often than those in area $\mathrm{R}$ and that the higher level of inter-individual aggres- sion resulted in elevated vigilance efforts by individu- als (Treves, 2000; Favreau et al., 2010; but see Slotow \& Coumi, 2000; Blumstein 
et al., 2002). If so, females feeding in poor areas stared at the closer grazing con- specifics for a longer time and interrupted their chew- ing activity more frequently than those feeding in the rich area, presumably to detect a potential aggres- sion earlier. In turn, their foraging efficiency would be further reduced by social monitoring, contribut- ing to limit their food intake rate in areas with poor resources (Ferretti et al., 2015). The results on grouping, aggressive and vigilance behaviour are consistent with those from the relevant endocrine correlates, supporting our prediction (1d). In most vertebrates, androgen levels are intimately linked to aggression in a mutual escalation (Adkins- Regan, 1981). Accordingly, individuals of areas P1 and P2, i.e. those where social aggression was most fre- quent, showed a greater concentration of faecal andro- gen metabolites than those inhabiting area $R$.

Faecal cortisol metabolites were also higher in the poor areas than in the rich one, suggesting that the endogenous stress response of chamois was greater in the former than in the latter. In turn, we suggest that pasture depletion can lead to a direct/indirect increase of hormone metabolites. A direct effect could depend on the stressful effect of lack of adequate food resources per se. An indirect effect might result from the stress induced by the comparatively greater risk of aggression between individuals. Moreover, the lower cortisol levels shown by chamois in the rich area, which had the largest groups, suggests that group size itself might mitigate stress (Michelena et al., 2012), as the presence of conspecifics does in gregari- ous species (for a review, see Kikusui et al., 2006). In all cases, levels of faecal cortisol metabolites would be driven ultimately by the availability of food resources which, in turn, would influence agonistic and grouping phenology, in addition to secretion of glucocorticoids. If this is the case, our results support the hypothesis that reduced food availability elicits stress (Kitaysky et al., 1999; Clinchy et al., 2004; but see Taillon \& Côté, 2008; Forristal et al., 2012; Le Saout et al., 2016). Even while accounting for confounding predictors, our mod- els assessed statistical differences on hormonal levels across sites. Nevertheless, our results should be inter- preted cautiously because of the limited sample size in areas $\mathrm{P} 1$ and $\mathrm{P} 2$, as a result of the local low density of chamois.

Resource depletion has cascading effects on social behaviour and the endocrine responses of individu- als. The complex interplay amongst group size, feed-ing interference and vigilance behaviour has been widely discussed (Elgar, 1989; Lima, 1995; Roberts, 1996; Lima et al., 1999; Beauchamp, 2001, 2008), but few studies have related it to resource availability (Beauchamp, 2009; Favreau et al., 2018). In spite of the limitations resulting from our individually unmarked experimental animals (see statistical assumptions, in the Material and Methods section), our results have shown that, irrespective of group size, a lower abundance of food resources can increase aggression between conspecifics which, in turn, elicits greater levels of alertness and physiological stress. Hence, we suggest that the trade-offs between grouping behav-iour, feeding interference and vigilance might be explained ultimately by availability of resources.

Increasing temperatures determined by climatic changes are influencing vegetation worldwide, with detrimental effects on the snowbed vegeta- tion of mountainous ecosystems (Schöb et al., 2009; Gottfried et al., 2012; Pauli et al., 2012). Cold-adapted vegetation includes forb-dominated patches, i.e. the best food resource for Apennine chamois (Ferrari et al., 1988). Over the last three decades, the abun- dance of the plants most grazed by chamois has greatly decreased in our area P1, i.e. the only area where data on the composition of the vegetation were available for both the 1980s and early 2010s (Ferrari et al., 1988; Lovari et al., 2014). In turn, an effect of increasing ambient temperature on the reduction in the nutritional quality of pasture for chamois may be suggested (cf. Ferretti et al., 2018). Moreover, in poor areas, the exploitation of resources by increasing pop- ulations of red deer has strongly accelerated pasture depletion (Lovari et al., 2014; Ferretti et al., 2015; cf. Anderwald et al., 2016, for northern chamois). Our findings suggest that environmental changes lead- ing to pasture depletion can ultimately disrupt the social behaviour and physiology of groupliving her- bivores. Behavioural plasticity is adaptive, especially when individuals cope with stressful situations and limiting factors (fish: Dill, 1983; reptiles: Cooper \& Pérez-Mellado, 2012; amphibians: Relyea, 2001; birds: Gross et al., 2010; mammals: Darmon et al., 2014). Accordingly, our data support the theoretical model proposed by Sirot (2000), which suggests that increased aggression is an evolutionary stable strat- egy when food resources are scarce.

\section{ACKNOWLEDGEMENTS}

We are indebted to D. Febbo, G. Rossi and A. Carrara for their continuous support and to the ALMNP staff for logistic 
support. D. Scornavacca, S. Bernardini, A. Cotza and V. Pietrocini helped with data collection in 2014 . We are grateful to L. Bartoš and J. Herrero for their helpful comments on an early draft of this manuscript.

D. M. Shackleton kindly edited our English and made comments on our last draft. We thank two anonymous reviewers for their helpful comments. Financial sup- port was provided by the Italian Ministry of University and Research (PRIN project no. 2010P7LFW4). The dataset analysed during the present study is available from the corresponding author on reasonable request.

S.L. and F.F. planned this study. N.F. participated in study planning, conducted most of the data collection and data analyses, wrote the first draft and participated in writing all drafts. F.F. participated in data collection and analyses and in writing up all drafts. S.L. supervised all stages of the study and participated in writing of all drafts. C.B. participated in data collection and analyses.

C.B. and N.P. participated in data collection. E.M. con- ducted hormone assays and wrote the relevant text. M.C.P. provided statistical advice and participated in data analyses. The authors declare no conflict of interest.

\section{REFERENCES}

Adkins-Regan E. 1981. Hormone specificity, androgen metabolism, and social behavior. The American Zoologist 21: 257-271.

Altmann J. 1974. Observational study of behavior: sampling methods. Behaviour 49: 227-267.

Anderwald P, Haller RM, Filli F. 2016. Heterogeneity in pri- mary productivity influences competitive interactions between red deer and Alpine chamois. PLoS One 11: e0146458.

Artese C, Allavena S, Baliva S, Bernoni M, Borlenghi F, Carfagnini M, Cirillo M, Damiani G, Di Benedetto S, Lalli G, Morini P, Pellegrini M, Pinchera F, Ricci

F.2017. Status of the golden eagle Aquila chrysaetos in Abruzzo. Avocetta 41: 77-80.

Barbosa A. 2002. Does vigilance always covary negatively with group size? Effects of foraging strategy. Acta Ethologica 5: 51-55.

Barnard CJ, Behnke JM, Sewell J. 1996. Social status and resistance to disease in house mice (Mus musculus): status-related modulation of hormonal responses in relation to immunity costs in different social and physical environ- ments. Ethology 102: 63-84.

Barnard CJ, Thompson DBA. 1985. Gulls and plovers: the ecology and behaviour of mixed species feeding groups. London: Croom Helm.

Bartoń K. 2012. MuMIn: multi-model inference. R package version 1.15.6. Available at: https://cran.r-project.org/web/ packages/MuMIn

Baruzzi C, Lovari S, Fattorini N. 2017. Catch me if you can: antipredatory behaviour of chamois to the wolf. Ethology Ecology \& Evolution 29: 589-598.

Beauchamp G. 2001. Should vigilance always decrease with group size? Behavioral Ecology and Sociobiology 51: 47-52.

Beauchamp G. 2008. What is the magnitude of the group-size effect on vigilance? Behavioral Ecology 19: 13611368.

Beauchamp G. 2009. How does food density influence vigi- lance in birds and mammals? Animal Behaviour 78: 223-231.

Beauchamp G. 2015. Animal vigilance. Monitoring predators and competitors. Boston: Elsevier.

Beauchamp G, Ruxton GD. 2003. Changes in vigilance with group size under scramble competition. The American Naturalist 161: 672-675.

Begon M, Townsend CRH, John L, Colin RT, John LH. 2006. Ecology. From individuals to ecosystems, 4 th edn. Malden: Blackwell Publishing.

Berger J. 1978. Group size, foraging, and antipredator ploys: an analysis of bighorn sheep decisions. Behavioral Ecology and Sociobiology 4: 91-99.

Blanchard P, Fritz H. 2007. Induced or routine vigilance while foraging. Oikos 116: 1603-1608.

Blumstein DT, Daniel JC, Ardon JG, Evans CS. 2002. Does feeding competition influence tammar wallaby time alloca- tion? Ethology 108: 937-945. 
Bocci A, Lovari S. 2011. Dispersal behaviour of red deer hinds. Ethology Ecology \& Evolution 23: 91-96.

Bolker BM, Skaug H, Magnusson A, Nielsen A. 2012. Getting started with the glmm ADMB package. Available at: http://glmmadmb.r-forge.r-project.org

Boonstra R. 2013. Reality as the leading cause of stress: rethinking the impact of chronic stress in nature. Functional Ecology 27: 11-23.

Bowman RI. 1961. Morphological differentiation and adap- tation in the Galapagos finches. University of California Publications in Zoology 58: 1-302.

Boyce MS. 1989. The Jackson elk herd: intensive wildlife management in North America. Cambridge: Cambridge University Press.

Bruno E, Lovari S. 1989. Foraging behaviour of adult female Apennine chamois in relation to seasonal variation in food supply. Acta Theriologica 34: 513-523.

Bubenik GA, Bubenik AB, Schams D, Leatherland JF. 1983. Circadian and circannual rhythms of LH, FSH, testos- terone $(T)$, prolactin, cortisol, $\mathrm{T}_{3}$ and $\mathrm{T}_{4}$ in plasma of mature,

male white-tailed deer. Comparative Biochemistry and

Physiology Part A: Comparative Physiology 76: 37-45.

Burnham KP, Anderson DR. 2002. Model selection and mul- timodel inference: a practical information-theoretic approach. New York: Springer-Verlag.

Caraco T. 1979. Time budgeting and group size: a test of the- ory. Ecology 60: 618-627.

Cederna A, Lovari S. 1985. The impact of tourism on cham- ois feeding activities in an area of the Abruzzo National Park, Italy. In: Cederna A, Lovari S, eds. The biology and management of mountain ungulates. London: Croom Helm, 216-225.

Chirichella R, Mustoni A, Apollonio M. 2015. Ecological drivers of group size in female Alpine chamois, Rupicapra rupicapra. Mammalia 79: 375-383.

Ciucci P, Tosoni E, Di Domenico G, Quattrociocchi F, Boitani L. 2014. Seasonal and annual variation in the food habits of Apennine brown bears, central Italy. Journal of Mammalogy 95: 572-586.

Clinchy M, Zanette L, Boonstra R, Wingfield JC, Smith JNM. 2004. Balancing food and predator pressure induces chronic stress in songbirds. Proceedings of the Royal Society B: Biological Sciences 271: 2473-2479.

Cooper Jr WE, Pérez-Mellado V. 2012. Historical influence of predation pressure on escape by Podarcis lizards in the Balearic Islands. Biological Journal of the Linnean Society 107: 254-268.

Corazza M, Tardella FM, Ferrari C, Catorci A. 2016. Tall grass invasion after grassland abandonment influences the availability of palatable plants for wild herbivores: insight into the conservation of the Apennine chamois Rupicaprapyr-enaica ornata. Environmental Management 57: 1247-1261.

Corlatti L, Béthaz S, von Hardenberg A, Bassano B, Palme R, Lovari S. 2012. Hormones, parasites and male mating tactics in Alpine chamois: identifying the mechanisms of life history trade-offs. Animal Behaviour 84: 1061-1070.

Corlatti L, Palme R, Lovari S. 2014. Physiological response to etho-ecological stressors in male Alpine chamois: time- scale matters! Die Naturwissenschaften 101: 577-586.

Côté SD, Festa-Bianchet M. 2001. Birthdate, mass and sur- vival in mountain goat kids: effects of maternal characteris- tics and forage quality. Oecologia 127: 230-238.

Creel S, Creel NM, Wildt DE, Monfort SL. 1992. Behavioral and endocrine mechanisms of reproductive suppression in Serengeti dwarf mongooses. Animal Behaviour 43: 231-245.

Cubaynes S, MacNulty DR, Stahler DR, Quimby KA, Smith DW, Coulson T. 2014. Density-dependent intraspe- cific aggression regulates survival in northern Yellowstone wolves (Canis lupus). The Journal of Animal Ecology 83: 1344-1356.

Dalmau A, Ferret A, Chacon G, Manteca X. 2007. Seasonal changes in fecal cortisol metabolites in Pyrenean chamois. Journal of Wildlife Management 71: 190-194.

Darmon G, Bourgoin G, Marchand P, Garel M, Dubray D, Jullien JM, Loison A. 2014. Do ecologically close spe- cies shift their daily activities when in sympatry? A test on chamois in the presence of mouflon. Biological Journal of the Linnean Society 111: 621-626. 
Dawkins MS. 2007. Observing animal behaviour: design and ana- lysis of quantitative data. New York: Oxford University Press.

De Groot P. 1980. Information transfer in a socially roost- ing weaver bird (Quelea quelea; Ploceinae): an experimental study. Animal Behaviour 28: 1249-1254.

Decristophoris PMA, von Hardenberg A, McElligott AG. 2007. Testosterone is positively related to the output of nematode eggs in male Alpine ibex (Capra ibex) feces. Evolutionary Ecology Research 9: 12771292.

Dill LM. 1983. Adaptive flexibility in the foraging behavior of fishes. Canadian Journal of Fisheries and Aquatic Sciences 40: 398-408.

Elgar MA. 1989. Predator vigilance and group size in mam- mals and birds. Biological Reviews 64: 13-33.

Emlen ST, Oring LW. 1977. Ecology, sexual selection, and the evolution of mating systems. Science 197: $215-223$.

Enquist M, Plane E, Röed J. 1985. Aggressive communi- cation in fulmars (Fulmarus glaeialis) about food. Animal Behaviour 33: 1007-1020.

Ezenwa VO, Stefan Ekernas L, Creel S. 2012. Unravelling complex associations between testosterone and parasite infection in the wild. Functional Ecology 26: 123-133.

Fabbri M, Boscagli G, Lovari S. 1983. The brown bear popu- lation of Abruzzo. Acta Zoologica Fennica 174: 163-164.

Favreau FR, Goldizen AW, Fritz H, Pays O. 2018. Food sup- ply fluctuations constrain group sizes of kangaroos and in turn shape their vigilance and feeding strategies. Animal Behaviour 135: 165-176.

Favreau FR, Goldizen AW, Pays 0. 2010. Interactions among social monitoring, anti-predator vigilance and group size in eastern grey kangaroos. Proceedings of the Royal Society B: Biological Sciences 277: 2089-2095.

Ferrari C, Rossi G, Cavani C. 1988. Summer food habits and quality of female, kid and subadult Apennine chamois, Rupicapra pyrenaica ornata Neumann, 1899 (Artiodactyla, Bovidae). Zeitschrift für Säugetierkunde 53: 170-177.

Ferretti F, Corazza M, Campana I, Pietrocini V, Brunetti C, Scornavacca D, Lovari S. 2015. Competition between wild herbivores: reintroduced red deer and Apennine cham- ois. Behavioral Ecology 26: 550-559.

Ferretti F, Costa A, Corazza M, Pietrocini V, Cesaretti G, Lovari S. 2014. Males are faster foragers than females: intersexual differences of foraging behaviour in the Apennine chamois. Behavioral Ecology and Sociobiology 68: 1335-1344. Ferretti F, Lovari S, Stephens P. 2018. Joint effects of wea-ther and interspecific competition on foraging behaviour and survival of a mountain herbivore. Current Zoologyzoy032,

https://doi.org/10.1093/cz/zoy032

Folstad I, Karter AJ. 1992. Parasites, bright males, and the immunocompetence handicap. The American Naturalist 139: 603-622.

Forristal VE, Creel S, Taper ML, Scurlock BM, Cross PC. 2012. Effects of supplemental feeding and aggregation on fecal glucocorticoid metabolite concentrations in elk. Journal of Wildlife Management 76:694702.

Forsyth DM. 2000. Habitat selection and coexistence of the Alpine chamois (Rupicapra rupicapra) and Himalayan tahr (Hemitragus jemlahicus) in the eastern Southern Alps, New Zealand. Journal of Zoology 252: 215-225.

Fortin D, Boyce MS, Merrill EH. 2004a. Multi-tasking by mammalian herbivores:overlapping processes during forag- ing. Ecology 85: 2312-2322.

Fortin D, Boyce MS, Merrill EH, Fryxell JM. 2004b. Foraging costs of vigilance in large mammalian herbivores. Oikos 107: 172-180.

Fox J, Weisberg S. 2011. An R companion to applied regres- sion, 2nd edn. Thousand Oaks: SAGE.

Fretwell SD, Lucas HR. 1970. On territorial behavior and other factors influencing habitat distribution in birds. Theoretical development. Acta Biotheoretica 19: 16-36.

Frid A. 1997. Vigilance by female Dall's sheep: interactions between predation risk factors. Animal Behaviour 53: 799-808. Gaillard JM, Festa-Bianchet M, Yoccoz NG, Loison A, Toïgo C. 2000. Temporal variation in fitness components and population dynamics of large herbivores. Annual Review 
of Ecology and Systematics 31: 367-393.

Gause GF. 1932. Experimental studies on the struggle for existence. Journal of Experimental Biology 9: 389-402.

Geist V. 1978. Life strategies, human evolution, environmen-tal design: toward a biological theory of health. New York: Springer-Verlag.

Gillman MP, Crawley MJ. 1990. A comparative evaluation of models of cinnabar moth dynamics. Oecologia 82: 437-445.

Goss-Custard JD, Clarke RT, Dit Durell SLV. 1984. Rates of food intake and aggression of oystercatchers Haematopus ostralegus on the most and least preferred mussel Mytilus edulis beds of the Exe Estuary.Journalof Animal Ecology 53: 233-245. Gottfried M, Pauli H, Futschik A, Akhalkatsi M, Barančok P, Alonso JLB, Coldea G, Dick J, Erschbamer B, Calzado MRF, Kazakis G, Krajči J, Larsson P, Mallaun M, Michelsen O, Moiseev D, Moiseev P, Molau U, Merzouki A, Nagy L, Nakhutsrishvili G, Pedersen B, Pelino G, Puşcaş M, Rossi G, Stanisci A, Theurillat JP, Tomaselli M, Villar L, Vittoz P, Vogiatzakis I, Grabherr

F.2012. Continent-wide response of mountain vegetation to climate change. Nature Climate Change 2: 111-115.

Gross K, Pasinelli G, Kunc HP. 2010. Behavioral plasticity allows short-term adjustment to a novel environment. The American Naturalist 176: 456-464.

Grottoli L. 2011. Assetto territoriale ed ecologia alimentare del lupo (Canis lupus) nel Parco Nazionale d'Abruzzo, Lazio e Molise. Unpublished PhD Thesis, Università di Roma La Sapienza.

Hadinger U, Haymerle A, Knauer F, Schwarzenberger F, Walzer C. 2015. Faecal cortisol metabolites to assess stress in wildlife: evaluation of a field method in free-ranging chamois. Methods in Ecology \& Evolution 6: 1349-1357.

Herrero J, Lovari S, Berducou C. 2008. Rupicapra pyr- enaica. The IUCN red list of threatened species 2008: e.T19771A9012711. Available at: http://dx.doi.org/10.2305/IUCN.UK.2008.RLTS.T19771A9012711.en

Hofmann RR. 1989. Evolutionary steps of ecophysiological adaptation and diversification of ruminants: a comparative view of their digestive system. Oecologia 78: 443-457.

Jarman P. 1974. The social organisation of antelope in rela- tion to their ecology. Behaviour 48: 215-267.

Kelley KW. 1980. Stress and immune function: a biblio- graphic review. Annales de Recherches Veterinaires. Annals of Veterinary Research 11: 445-478.

Kikusui T, Winslow JT, Mori Y. 2006. Social buffering: relief from stress and anxiety. Philosophical Transactions of the Royal Society B: Biological Sciences 361:2215-2228.

Kiley-Worthington M. 1978. The social organisation of a small captive group of eland, oryx and roan antelope with an analysis of personality profiles. Behaviour 66: 32-55.

Kitaysky AS, Piatt JF, Wingfield JC, Romano M. 1999. The adrenocortical stress-response of black-legged kitti- wake chicks in relation to dietary restrictions. Journal of Comparative Physiology B 169: 303-310.

Konjević D, Janicki Z, Slavica A, Severin K, Krapinec K, Božić F, Palme R. 2011. Non-invasive monitoring of adren- ocortical activity in freeranging fallow deer (Dama dama L.). European Journal of Wildlife Research 57: 77-81.

Krämer A. 1969. Soziale organisation und sozialverhalten einer gemspopulation (Rupicapra rupicapra L.) der Alpen. Zeitschrift für Tierpsychologie 26: 889-964.

Krebs CJ, Gilbert BS, Boutin S, Sinclair ARE, Smith JNM. 1986. Population biology of snowshoe hares: I. Demography of food-supplemented populations in the southern Yukon, 1976-84. Journal of Animal Ecology 55: 963-982.

Latini R, Asprea A, Pagliaroli D. 2015. Stima della densità della popolazione di cervo e di capriolo nel Parco Nazionale d'Abruzzo, Lazio e Molise. Ente Parco Nazionale d'Abruzzo, Lazio, Molise. Available at: http://www.parcoabruzzo.it/Pdf/ progetti/PNALMpro155-1.pdf

Latini R, Asprea A, Pagliaroli D, Gentile L, Argenio A, Di Pirro V. 2013. Life+ Coornata. Development of coordinated protection measures for Apennine chamois (Rupicapra pyr- enaica ornata). Stato dell'arte delle azioni C2 e C6. Available at: http://www.parcoabruzzo.it/pdf/Relazione_conteggio_camoscio_finale_2012.pdf

Le Saout S, Massouh M, Martin JL, Presseault-Gauvin H, Poilvé E, Côté SD, Picot D, Verheyden H, 
Chamaillé- Jammes S. 2016. Levels of fecal glucocorticoid metabolites do not reflect environmental contrasts across islands in black-tailed deer (Odocoileus hemionus sitkensis) popula- tions. Mammal Research 61: 391-398.

Lee JC. 1980. Comparative thermal ecology of two lizards.

Oecologia 44: 171-176.

Lima SL. 1987. Vigilance while feeding and its relation to the risk of predation. Journal of Theoretical Biology 124: 303-316. Lima SL. 1995. Back to the basics of antipredatory vigilance:

the group size effect. Animal Behaviour 49: 11-20.

Lima SL, Zollner PA, Bednekoff PA. 1999. Predation, scramble competition, and the vigilance group size effect in dark-eyed juncos (Junco hyemalis). Behavioral Ecology and Sociobiology 46: 110-116.

Lipetz VE, Bekoff M. 1982. Group size and vigilance in pronghorns. Zeitschrift für Tierpsychologie 58: $203-216$.

Locati M, Lovari S. 1990. Sexual differences in aggressive behaviour of the Apennine chamois. Ethology 84: 295-306. Loison A, Darmon G, Cassar S, Jullien JM, Maillard D.

2008. Age- and sex-specific settlement patterns of cham- ois (Rupicapra rupicapra) offspring. Canadian Journal of Zoology 86: 588-593.

Loison A, Jullien JM, Menaut P. 1999. Subpopulation struc- ture and dispersal in two populations of chamois. Journalof Mammalogy 80: 620-632.

Lovari S. 1985. Behavioural repertoire of the Abruzzo chamois, Rupicapra pyrenaica ornata Neumann, 1899 (Artiodactyla: Bovidae). Säugetierkundliche Mitteilungen 32: 113-116.

Lovari S, Cosentino R. 1986. Seasonal habitat selection and group size of the Abruzzo chamois (Rupicapra pyrenaica ornata). Italian Journal of Zoology 53: 73-78.

Lovari S, Fattorini N, Boesi R, Bocci A. 2015. Male ruff colour as a rank signal in a monomorphic-horned mammal: behavioural correlates. The Science of Nature 102: 1-12.

Lovari S, Ferretti F, Corazza M, Minder I, Troiani N, Ferrari C, Saddi A. 2014. Unexpected consequences of reintroductions: competition between reintroduced red deer and Apennine chamois. Animal Conservation 17: 359-370.

Lovari S, Rolando A. 2004. Guida allo studio degli animali in natura. Torino: Bollati Boringhieri.

Macdonald DW. 1983. The ecology of carnivore social behav-iour. Nature 301: 379-384.

Maiorano L, Boitani L, Monaco A, Tosoni E, Ciucci P. 2015. Modeling the distribution of Apennine brown bears during hyperphagia to reduce the impact of wild boar hunt- ing. European Journal of Wildlife Research 61: 241-253.

Mancinelli S, Boitani L, Ciucci P. 2018. Determinants of home range size and space use patterns in a protected wolf (Canis lupus) population in central Apennines, Italy. Canadian Journal of Zoology. https://doi.org/10.1139/cjz-2017-0210

Martin AM, Presseault-Gauvin H, Festa-Bianchet M, Pelletier F. 2013. Male mating competitiveness and age- dependent relationship between testosterone and social rank in bighorn sheep. Behavioral Ecology and Sociobiology 67: 919-928. McDougall PL, RuckstuhI KE. 2018. Vigilance behaviour is more contagious when chewing stops: examining the charac- teristics of contagious vigilance in bighorn sheep. Behavioral

Ecology and Sociobiology 72: 143.

Melis C, Jędrzejewska B, Apollonio M, Bartoń KA, Jędrzejewski W, Linnell JD, Kojola I, Kusak J, Adamic M, Ciuti S., Delehan I, Dykyy I, Krapinec K, Mattioli L, Sagaydak A, Samchuk N, Schmidt N, Shkvyrya M, Sidorovich VE, Zawadzka B, Zhyla S. 2009. Predation has a greater impact in less productive environments: vari- ation in roe deer, Capreolus capreolus, population dens- ity across Europe. Global Ecology and Biogeography 18: 724-734.

Meyer A. 1989. Cost of morphological specialization: feed-ing performance of the two morphs in the trophically poly- morphic cichlid fish, Cichlasoma citrinellum. Oecologia 80: 431-436.

Michelena P, Pillot MH, Henrion C, Toulet S, Boissy A, Bon R. 2012. Group size elicits specific physiological response in herbivores. Biology Letters 8: 537-539.

Miller RS. 1967. Pattern and process in competition. Advances in Ecological Research 4: 1-74. 
Millspaugh JJ, Washburn BE. 2004. Use of fecal glucocortic- oid metabolite measures in conservation biology research: considerations for application and interpretation. General and Comparative Endocrinology 138: 189199.

Molvar EM, Bowyer RT. 1994. Costs and benefits of group living in a recently social ungulate: the Alaskan moose. Journal of Mammalogy 75: 621-630.

Mooring MS, Patton ML, Lance VA, Hall BM, Schaad EW, Fetter GA, Fortin SS, McPeak KM. 2006. Glucocorticoids of bison bulls in relation to social status. Hormones and Behaviour 49: 369-375.

Möstl E, Messmann S, Bagu E, Robia C, Palme R. 1999. Measurement of glucocorticoid metabolite concentrations in faeces of domestic livestock. Journal of Veterinary Medicine 46: 621-631.

Möstl E, Palme R. 2002. Hormones as indicators of stress.

Domestic Animal Endocrinology 23: 67-74.

Parker GA. 1974. Assessment strategy and the evolution of fighting behaviour. Journal of Theoretical Biology 47: 223-243.

Pasch B, George AS, Hamlin HJ, Guillette LJ, Phelps SM. 2011. Androgens modulate song effort and aggression in Neotropical singing mice. Hormones and Behaviour 59: 90-97.

Patalano M, Lovari S. 1993. Food habits and trophic niche overlap of the wolf Canis lupus (L. 1758) and the red fox Vulpes vulpes (L. 1758) in a Mediterranean mountain area. Revue D'Écologie La Terre et La Vie 48: $279-294$.

Pauli H, Gottfried M, Dullinger S,Abdaladze O,Akhalkatsi M, Alonso JLB, Coldea G, Dick J, Erschbamer B, Calzado MRF, Ghosn D, Holten JI, Kanka R, Kazakis G, Kollár J, Larsson P, Moiseev P, Moiseev D, Molau U, Mesa JM, Nagy L, Pelino G, Puşcaş M, Rossi G, Stanisci A, Syverhuset AO, Theurillat JP, Tomaselli M, Unterluggauer P, Villar L, Vittoz P, Grabherr G 2012. Recent plant diversity changes on Europe's mountain sum- mits. Science 336: 353-355.

Pavitt AT, Pemberton JM, Kruuk LE, Walling CA. 2016. Testosterone and cortisol concentrations vary with repro- ductive status in wild female red deer. Ecology and Evolution 6: 1163-1172.

Pavitt AT, Walling CA, Möstl E, Pemberton JM, Kruuk LE. 2015. Cortisol but not testosterone is repeatable and varies with reproductive effort in wild red deer stags. General and Comparative Endocrinology 222: 6268.

Pecorella I, Ferretti F, Sforzi A, Macchi E. 2016. Effects of culling on vigilance behaviour and endogenous stress response of female fallow deer. Wildlife Research 43:189-196. Pépin D, Gerard JF. 2008. Group dynamics and local popula- tion density dependence of group size in the Pyrenean cham-

ois, Rupicapra pyrenaica. Animal Behaviour 75: 361-369.

Pesaresi S, Galdenzi D, Biondi E, Casavecchia S. 2014. Bioclimate of Italy: application of the worldwide bioclimatic classification system. Journal of Maps 10: 538-553.

Pettorelli N, Gaillard JM, Van Laere G, Duncan P, Kjellander P, Liberg O, Delorme D, Maillard D. 2002. Variations in adult body mass in roe deer: the effects of popu- lation density at birth and of habitat quality. Proceedings of the Royal Society B: Biological Sciences 269: 747-753.

Pettorelli N, Pelletier F, Hardenberg AV, Festa-Bianchet M, Côté SD. 2007. Early onset of vegetation growth vs. rapid green-up: impacts on juvenile mountain ungulates. Ecology 88: 381-390.

Primi R, Filibeck G, Amici A, Bückle C, Cancellieri L, Di Filippo A, Gentile C, Guglielmino A, Latini R, Mancini LD, Mensing SA, Rossi CM, Rossini F, Scoppola A, Sulli C, Venanzi R, Ronchi B, Piovesan G. 2016. From Landsat to leafhoppers: a multidisciplinary approach for sustainable stocking assessment and ecological monitoring in mountain grasslands. Agriculture, Ecosystems and Environment 234: 118-133.

Pulliam HR. 1973. On the advantages of flocking. Journal of Theoretical Biology 38: 419-422.

Puorger A, Rossi C, Haller RM, Anderwald P. 2018. Plastic adaptations of foraging strategies to variation in forage quality in Alpine chamois. Canadian Journal of Zoology 96: 269-275.

R Core Team. 2013. R: A language and environment for statistical computing. Vienna: R Foundation for Statistical Computing. Available at: http://www.R-project.org

Reeder DM, Krämer KM. 2005. Stress in free-ranging mam- mals: integrating physiology, ecology, and natural 
history. Journal of Mammalogy 86: 225-235.

Relyea RA. 2001. Morphological and behavioral plasticity of larval anurans in response to different predators. Ecology 82: 523-540.

Roberts G. 1996. Why individual vigilance declines as group size increases. Animal Behaviour 51: 1077-1086.

Rohwer S, Rohwer FC. 1978. Status signalling in Harris sparrows: experimental deceptions achieved. Animal Behaviour 26: 1012-1022.

Ruckstuhl KE, Festa-Bianchet M, Jorgenson JT. 2003. Bite rates in Rocky Mountain bighorn sheep (Ovis canaden- sis): effects of season, age, sex and reproductive status. Behavioral Ecology and Sociobiology 54: 167-173.

Saltz D, White GC. 1991. Urinary cortisol and urea nitrogen responses to winter stress in mule deer. Journal of Wildlife Management 55: 1-16.

Sapolsky RM. 1992. Neuroendocrinology of the stress response. In: Becker JB, Breedlove SM, Crews D, eds. Behavioral endocrinology. Cambridge: MIT Press, 287-324.

Schaller GB. 1977. Mountain monarchs. Chicago: The University of Chicago Press.

Schöb C, Kammer PM, Choler P, Veit H. 2009. Small-scale plant species distribution in snowbeds and its sensitivity to climate change. Plant Ecology 200: 91-104.

Schoener TW. 1973. Population growth regulated by intraspe- cific competition for energy or time: some simple representa- tions. Theoretical Population Biology 4:56-84.

Scornavacca D, Brunetti C. 2015. Cooperative defence of female chamois successfully deters an eagle attack. Mammalia 80: 453-456.

Scornavacca D, Lovari S, Cotza A, Bernardini S, Brunetti C, Pietrocini V, Ferretti F. 2016. Pasture quality affects juvenile survival through reduced maternal care in a moun- tain-dwelling ungulate. Ethology 122: 807817.

Sheriff MJ, Dantzer B, Delehanty B, Palme R, Boonstra

R. 2011. Measuring stress in wildlife: techniques for quanti- fying glucocorticoids. Oecologia 166: 869-887.

Sheriff MJ, Krebs CJ, Boonstra R. 2010. Assessing stress in animal populations: do fecal and plasma glucocorticoids tell the same story? General and Comparative Endocrinology 166: 614-619.

Shopland JM. 1987. Food quality, spatial deployment, and the intensity of feeding interference in yellow baboons (Papio cyno- cephalus). Behavioral Ecology and Sociobiology 21:149-156.

Sirot E. 2000. An evolutionarily stable strategy for aggressive- ness in feeding groups. Behavioral Ecology 11: 351356.

Skarstein F, Folstad I, Liljedal S. 2001. Whether to repro- duce or not: immune suppression and costs of parasites dur- ing reproduction in the Arctic charr. Canadian Journal of Zoology 79: 271-278.

Slotow R, Coumi N. 2000. Vigilance in bronze mannikin groups: the contributions of predation risk and intra-group competition. Behaviour 137: 565-578.

Šprem N, Zanella D, Ugarković D, Prebanić I, Gančević P,Corlatti L. 2015. Unimodal activity pattern in forestdwell- ing chamois: typical behaviour or interspecific avoidance? European Journal of Wildlife Research 61: 789-794.

Symington MM. 1988. Food competition and foraging party size in the black spider monkey (Ateles paniscus Chamek). Behaviour 105: 117-132.

Taillon J, Côté SD. 2008. Are faecal hormone levels linked to win- ter progression, diet quality and social rank in young ungulates? An experiment with white-tailed deer (Odocoileus virginianus) fawns. Behavioral Ecology and Sociobiolgy 62: 1591-1600.

Taitt MJ, Krebs CJ. 1981. The effect of extra food on small rodent populations: II. Voles (Microtus townsendii). Journal of Animal Ecology 50: 125-137.

Tauber CA, Tauber MJ. 1987. Food specificity in predacious insects: a comparative ecophysiological and genetic study. Evolutionary Ecology 1: 175-186.

Therrien JF, Côté SD, Festa-Bianchet M, Ouellet JP. 2007. Conservative maternal care in an iteroparous 
mam- mal: a resource allocation experiment. Behavioral Ecology and Sociobiology 62: 193-199.

Thouless CR. 1990. Feeding competition between grazing red deer hinds. Animal Behaviour 40: 105-111.

Titman D. 1976. Ecological competition between algae: experi- mental confirmation of resource-based competition theory. Science 192: 463-465.

Treves A. 2000. Theory and method in studies of vigilance and aggregation. Animal Behaviour 60: 711-722.

Underwood R. 1982. Vigilance behaviour in grazing African antelopes. Behaviour 79: 81-107.

Volterra V. 1926. Fluctuations in the abundance of a species considered mathematically. Nature 118: 558-560.

Walde SJ, Davies RW. 1984. The effect of intraspecific inter-ference on Kogotus nonus (Plecoptera) foraging behaviour. Canadian Journal of Zoology 62: 2221-2226.

Walther F. 1974. Some reflections on expressive behavior in combat and courtship of certain horned ungulates. In: Geist V, Walther F, eds. Behavior of ungulates and its relation to management. Morges: IUCN, 56-106.

Winnie J Jr, Creel S. 2007. Sex-specific behavioural responses of elk to spatial and temporal variation in the threat of wolf predation. Animal Behaviour 73:215-225.

Wise DH, Wagner JD. 1992. Evidence of exploitative com- petition among young stages of the wolf spider Schizocosa ocreata. Oecologia 91: 7-13.

Yee TW. 2015. Vector generalized linear and additive models: with an implementation in R. New York: Springer.

Zuur AF, leno EN, Walker NJ, Saveliev AA, Smith GM. 2009. Mixed effects models and extensions in ecology with R. New York, NY: Springer.

Zwijacz-Kozica T, Selva N, Barja I, Silván G, Martínez- Fernández L, Illera JC, Jodłowski M. 2013. Concentration of fecal cortisol metabolites in chamois in relation to tour-ist pressure in Tatra National Park (South Poland). Acta Theriologica 58: 215-222.

\section{SUPPORTING INFORMATION}

Additional Supporting Information may be found in the online version of this article at the publisher's web-site:

Table S1. Possible influencing predictors of behavioural and endocrine aspects evaluated in our analyses, with supporting references.

Table S2. Behavioural and hormonal indicators investigated through model selection, with relevant error distributions (in parentheses: link function), fixed and random (in parenthesis) effects considered in global models and number of models run. $N$, number of observations; $\mathrm{ZT}$, zero truncated.

Table S3. Result of model selection: best models and models with $\Delta \mathrm{AICc}<2$, each with $K, \Delta \mathrm{AICc}$, log-likelihood, AICc value and weight. The effect of site, when present, is shown in bold. 